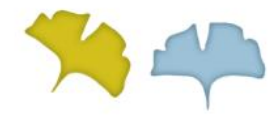

THE UNIVERSITY OF BRITISH COLUMBIA

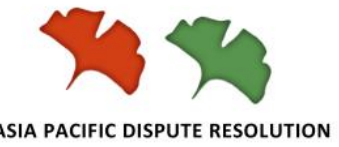

\title{
Private Food Safety Standards, Obligations of Governments, and Unresolved Questions in Contemporary WTO Law
}

\author{
Moshe Hirsch \\ Faculty of Law \\ Hebrew University of Jerusalem
}

APDR Working Paper Series
Volume 1 Number 1

ISSN 2371-6304

(c) (†) $\ominus$

by Moshe Hirsch, 2018.

This article is made available as part of the Asia Pacific Dispute Resolution

Working Paper Series and is licensed under a Creative Commons Attribution-

NonCommercial-NoDerivatives 4.0 International License

(CC-BY-NC-ND)

This paper has also been published as part of the Hebrew University of Jerusalem

Legal Studies Research Paper Series No. 17-18, March 2017. 


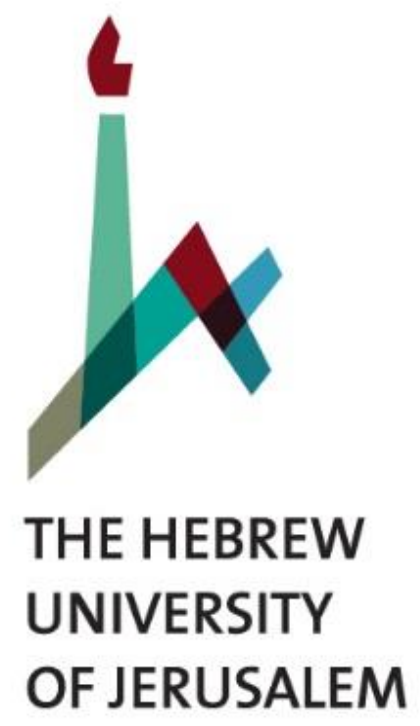

The Hebrew University of Jerusalem Faculty of Law

Mt. Scopus, Jerusalem 9765418

Israel

\section{Private Food Safety Standards, Obligations of Governments, and Unresolved Questions in Contemporary WTO Law}

\section{Moshe Hirsch}

Hebrew University of Jerusalem Legal Studies Research Paper Series No. 17-18 
The Hebrew University of Jerusalem

\section{Faculty of Law}
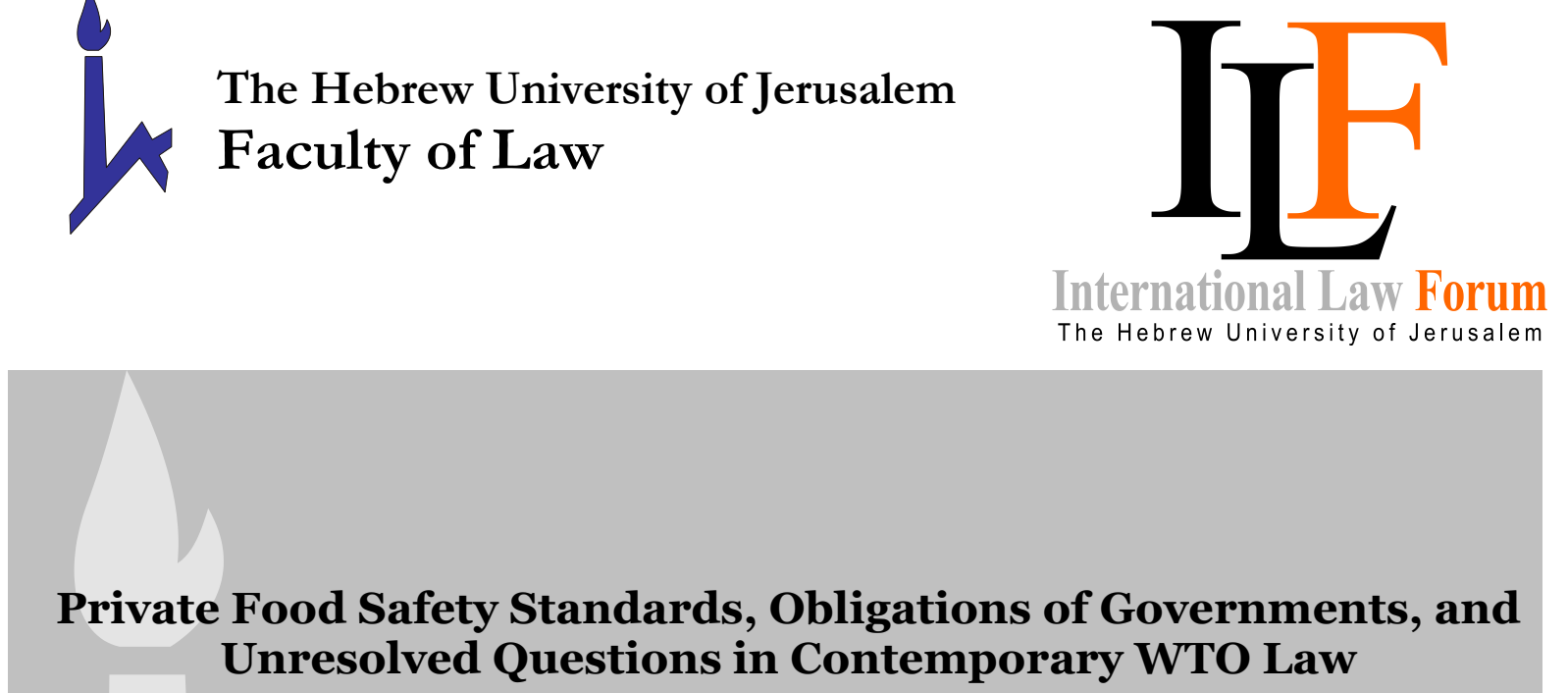

Paper submitted to the Workshop of the ESIL Interest Group on International Economic Law (Riga 7 September, 2016)

Research Paper No. 01-17

March 2017

March 21, 2017

Published by the International Law Forum of the Hebrew

University of Jerusalem Law Faculty

Editor: Prof. Tomer Broude

Assistant Editor: Rebecca Baskin Zafrir

To subscribe, free of charge, contact: ssrn@savion.huji.ac.il

This paper can be downloaded free of charge 
Paper submitted to the Workshop of the ESIL Interest Group on International Economic Law (Riga 7 September, 2016)

\section{Private Food Safety Standards, Obligations of Governments, and Unresolved Questions in Contemporary WTO Law}

Moshe Hirsch ${ }^{1}$

\section{Initial Draft - Please Don't Quote}

\section{Introduction}

II. The Promise and Pitfalls of Private Standards

III. Private Standards and the WTO SPS Agreement

IV. Private Parties, Members' Responsibility and 'Due Diligence' Obligations in WTO Law

$V$. The Way Forward: Implementing the SPS's Implementation Clause

\section{Introduction}

The rapid proliferation of private standards (PSs) schemes has attracted the attention of numerous experts and policy-makers, and proved to be a sensitive issue for the WTO's members. On-going discussions in the WTO bodies raise significant questions regarding the proper interpretation of existing provisions included in WTO instruments (prominently the SPS and TBT agreements), as well as fundamental issues relating to the obligations of WTO members vis-a-vis private standard-setting entities.

The spread of private food safety standards is explained by, inter alia, the processes of globalization and vertical integration of the food supply chain, expansion of supermarkets in food retailing, increasing consumer concerns about food safety, strengthening of regulation on food safety, and increasing legal requirements imposed on firms to demonstrate 'due diligence' in the prevention of food safety risks. ${ }^{2}$ Though such PSs interact with several WTO agreements, this paper focuses on food standards and the SPS Agreement. The main entities developing private food

\footnotetext{
${ }^{1}$ Maria Von Hofmannsthal Chair in International Law, Faculty of Law and Department of International Relations, Hebrew University of Jerusalem.

${ }^{2}$ See, e.g., - WTO, Private Standards ad the SPS Agreement-Committee on Sanitary and Phytosanitary Measures, Note by the Secretariat (24 January 2007) G/SPS/GEN/746 [hereinafter 'WTO 2007 Report']; Spencer Henson and John Humphrey, 'Understanding the Complexities of Private Standards in Global Agri-Food Chains' (2008), 5 <https://www.ids.ac.uk/files/dmfile/HensonHumphreyLeuvenOct08.pdf> accessed 15 August 2016; Mariela Maidana-Eletti, 'International Food Standards and WTO Law' (2014) 19 Deakin LR 1, 18-19.
} 
safety standards are large supermarket chains and private associations initiated by such major retailers; and they are commonly audited by private certification bodies (e.g., GlobalG.A.P.). ${ }^{3}$ Products identified as being most affected by these standards are fresh fruit and vegetables and fresh, chilled or frozen meat. ${ }^{4}$

\section{The Promise and Pitfalls of Private Standards}

Though PSs are not legally binding, they occasionally constitute 'industry norms' and significantly constrain producers and suppliers, thus influencing international trade flows. Where a group of food retailers constitutes a high proportion of sales, the option for suppliers that do not participate in such standards schemes is significantly reduced. ${ }^{5}$ PSs address new risks in a relatively rapid manner that is not subject to cumbersome governmental bureaucratic processes. They may fill gaps in existing governmental regulatory framework, and occasionally accelerate the enactment of official standards. Private food safety standards frequently provide retailers with a 'due diligence defence', ${ }^{6}$ may give brands a better reputation, and assist suppliers in accessing multiple markets and promote productivity (thus, they may also have 'trade creation' effects). ${ }^{7}$

PSs may also constitute non-tariff barriers (NTBs). Such restrictive impacts and the multiplication of schemes has led some countries and economic operators, particularly in developing countries and small-medium-sized enterprises, to raise significant concerns. Such concerns emphasize, inter alia, that certain PSs present

\footnotetext{
${ }^{3}$ Antoine Bernard de Raymond and Laure Bonnaud, 'Beyond the Public-Private Divide: GLOBALGAP as a Regulation Repository for Farmers' (2014) 21 International Journal of Sociology of Agriculture and Food 227, 229-230.

${ }^{4}$ WTO, 'Food safety body agrees to e-working group "time out" on definition of private standards', WTO 2015 News Items (26-27 March 2015) $<$ https://www.wto.org/english/news_e/news15_e/sps_26mar15_e.htm> accessed 15 August 2016 [Hereinafter WTO 2015 News Report].

${ }^{5}$ WTO 2007 report , above $\mathrm{n} 2$, at 3.

${ }^{6}$ See, e.g., Henson and Humphrey, above n 2, at 7.

${ }^{7}$ See, e.g., WTO, 'Members take first steps on private standards in food safety, animal-plant health' WTO 2011 News Items (30-31 March 2011)

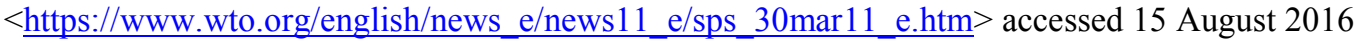
[Hereinafter WTO 2011 News Report]; WTO 2007 Report, above n 2, at 3; Maidana-Eletti, above n 2 , at 19-20
} 
more stringent requirements than those established in national or international standards; that they are not always scientifically justified; that they impose disproportionate burden on small-scale producers; that they do not always grant due consideration to their restrictive effects on producers in developing countries; and that they are established without transparency, consultations or appeal systems. ${ }^{8}$

The fact that most PSs have been adopted in developed countries, and that small producers and suppliers in developing countries encounter special difficulties in meeting these standards (often related to weaker financial, technological and institutional capacity $)^{9}$ has raised particular alarm with many developing countries. ${ }^{10}$ Thus, Pascal Liu (FAO) explains:

For those developing economies that rely on exports, losing market access will translate into a loss of vital export earnings, which jeopardizes economic and social development. Further, exclusion from international markets may shut them out from sources of expertise, inputs and technology. ${ }^{11}$

\section{Private Standards and the WTO SPS Agreement}

Since 2005, WTO bodies have discussed various issues relating to the effects of PSs and the WTO legal rules applicable to them. A significant debate has taken place in the SPS Committee; and has failed to produce an agreement on the essential issues

\footnotetext{
${ }^{8}$ WTO 2011 News Report, above n 7; see also WTO 2007 Report, above n 2, at 3-4; Christiane Wolff, 'Private Standards and the WTO Committee on Sanitary and Phytosanitary Measures'(World Organization for Animal Health) 2008 Conf. OIE 87, $91<\underline{\text { http://www.oie.int/doc/ged/D6061.PDF }>}$ accessed 15 August 2016. [Hereinafter OIE 2008]

${ }^{9}$ On the financial, technological and institutional difficulties of developing countries in compliance with sanitary standards, see Melaku Desta and Moshe Hirsch, 'The African Countries in the World Trading System: International Trade, Domestic Institutions and the Role of International Law' (2012) 61 ICLQ 127, at 151 et seq.

${ }^{10}$ See, e.g., WTO 2015 News Report, above n 4; Pascal Liu, 'Private standards in international trade: issues and opportunities' (WTO Workshop on Environment-Related Private Standards, Geneva, 9 July 2009), 17; WTO, 'Members set to agree on regionalization, improved SPS transparency' WTO 2008 News Items (2-3 April 2008)

$<$ https://www.wto.org/english/news_e/news08 e/sps apr08 e.htm> accessed 15 August 2016; Makane Moïse Mbengue, 'Private standards and WTO law' (6 April 2011) 5(1) BioRes Trade and Environment Review < http://archive-ouverte.unige.ch/unige:56168/ATTACHMENT01 > accessed 15 August 2016.

${ }^{11}$ Liu, above n 10.
} 
(including disagreement on the definition of 'private standards for food safety'). ${ }^{12}$ The principal bones of contention relate to the application of the SPS Agreement to private standards (mainly regarding Article 1.1 of the SPS Agreement and Article 1 of Annex A) and the WTO members' obligations vis-à-vis private standard-setting bodies (mainly regarding Article 13 of the SPS Agreement).

Article 1.1. of the SPS Agreement provides as follows:

This Agreement applies to all sanitary and phytosanitary measures which may, directly or indirectly, affect international trade. Such measures shall be developed and applied in accordance with the provisions of this Agreement.

And Article 1.1 of Annex A to the SPS Agreement adds:

1. Sanitary or phytosanitary measure - Any measure applied: (a) to protect animal or plant life or health within the territory of the Member from risks arising from the entry, establishment or spread of pests, diseases, disease-carrying organisms or disease-causing organisms; (b) to protect human or animal life or health within the territory of the Member from risks arising from additives, contaminants, toxins or disease-causing organisms in foods, beverages or feedstuffs; (c) to protect human life or health within the territory of the Member from risks arising from diseases carried by animals, plants or products thereof, or from the entry, establishment or spread of pests; or (d) to prevent or limit other damage within the territory of the Member from the entry, establishment or spread of pests.

Though yet no official determination has been made with regards to whether or not private food safety standards are covered by the above provisions, it is noteworthy that the text of these definitions adopts a broad language and does not limit the application of the SPS agreement only to measures undertaken by governmental

\footnotetext{
${ }^{12}$ On the discussions on the WTO SPS Committee, see, e.g., WTO 2015 News Report, above n 4 WTO, 'Members to try new approach for defining private sanitary-phytosanitary standards' WTO 2014 News Items (25-26 Match 2014)

$<$ https://www.wto.org/english/news_e/news14_e/sps_25mar14_e.htm> accessed 15 August 2016; WTO, Committee on Sanitary and Phytosanitary Measures - Summary of the Meeting of 15 and 17 October 2014, note by the Secretariat (2 December 2014) G/SPS/R/76, at para 11.9.; WTO 2011 News Report, above n 7; WTO 2007 Report, above n 2; Petros C. Mavroidis and Robert Wolfe, 'Private Standards and the WTO: Reclusive No More' European University Institute Working Paper RSCAS 2016/17, 8-9 $<$ http://cadmus.eui.eu/bitstream/handle/1814/40384/RSCAS_2016 17.pdf? sequence=1\&isAllowed= y> accessed 15 August 2016.
} 
authorities. Some WTO members and scholars argue, however, that other provisions of the SPS Agreement clearly refer to the rights and obligations of the WTO member states, and that the above definitions do not explicitly apply to standards adopted by private bodies. $^{13}$

As to the WTO member states' obligations regarding PSs, Article 13 directly addresses the responsibility of members regarding the implementation of the SPS Agreement. The first sentence provides that WTO members are "fully responsible" for the observance of all obligations established by the Agreement; the second sentence binds the members to formulate and implement 'positive measures' in support of the observance of the Agreement's provisions by other than central government bodies; the third sentence (examined in detail below) delineates the duties of WTO members with regard to compliance by 'non-governmental entities' with the SPS Agreement; the fourth sentence addresses members' duties regarding regional, non-governmental entities, and local governmental bodies; and the fifth sentence requires members to rely on the services of non-governmental entities only if the latter comply with the provisions of the SPS Agreement.

The third sentence of Article 13 is particularly pertinent to WTO members' obligations regarding compliance by private entities with the SPS Agreement:

Members shall take such reasonable measures as may be available to them to ensure that non-governmental entities within their territories, as well as regional bodies in which relevant entities within their territories are members, comply with the relevant provisions of this Agreement.

This sentence sparked controversy among WTO members, particularly with regards to the question of whether the above term "non-governmental entities" refers to private standard-setting entities as well. Some members, prominently developing countries, asserted that WTO governments are responsible to ensure that standards

\footnotetext{
${ }^{13}$ On the different views of the WTO members regarding Article 1.1. and the application of the SPS Agreement, see, e.g., WTO, Committee on Sanitary and Phytosanitary Measures -Report of the Ad Hoc Working Group on SPS-Related Private Standards to the SPS Committee (3 March 2011) G/SPS/W/256, page 11, para 26 [Hereinafter WTO Ad Hoc Group Report]
} 
adopted by such entities are consistent with the SPS Agreement. Other members, prominently developed countries, contended that PSs are not covered by the SPS Agreement and that governments should not interfere in the development of PSs. ${ }^{14}$ Some members argue that Article 13 applies only in cases where WTO members rely on services provided by non-governmental entities to implement SPS measures. ${ }^{15}$ Experts' writings also reveal disagreement regarding the interpretation of the third sentence of Article 13. While some authors are of the view that this provision applies to the relations between WTO members and private standard setting-bodies, ${ }^{16}$ other experts express doubts ${ }^{17}$ or argue that article 13 is not applicable to such private bodies. ${ }^{18}$

A careful analysis of the third sentence of Article 13 indicates that while it does not impose direct obligations on private standard-setting entities, the ordinary meaning of the text suggests that the latter bodies are included in the term 'nongovernmental entities' (private standard-setting bodies are not governmental in their nature). Accordingly, under this provision, WTO members are bound to employ reasonable measures available to them in order to ensure that private-standard setting bodies operating in their territories comply with the relevant provisions of the SPS Agreement. The text of the third sentence does not restrict its application (nor does Article 1.1.) to governmental entities or those endowed with some governmental powers. As discussed below, this interpretation of Article 13 is also consistent with the general aims of the WTO as well as with the need to cope with recent trends in the international economic system.

\footnotetext{
${ }^{14}$ See, e.g., WTO 2015 News Report, above n 4; OIE 2008, above n 8, at 90. See also Mavroidis and Wolfe, above n 12, at 9

${ }^{15}$ WTO Ad Hoc Group Report, above n 13, at para 10

${ }^{16}$ See, e.g., Denise Prévost, 'Private Sector Food-Safety Standards and the SPS Agreement: Challenges and Possibilities' (2008) 33 South African Yearbook of International Law 1, at 20-22;

${ }^{17}$ See, e.g., Mavroidis and Wolfe, above n 12, at 2, 7

${ }^{18}$ Alessandra Arcuri, 'The TBT Agreement and Private Standards' in Michael Trebilcock and Tracey Epps (eds), Research Handbook on the TBT Agreement ( Edward Elgar Publishing, 2013) 485, at 518-519..
} 


\section{Private Parties, Members' Responsibility and 'Due Diligence' Obligations in WTO Law}

The attitude of many WTO members' delegates and the organization's officials regarding the non-application of Article 13 to private standard-setting bodies is informed by the prevalent character of the WTO law and the legal culture prevailing within the WTO community. The WTO is clearly an inter-governmental organization and its obligations are mostly assigned to the governments of its members. In absence of contrary indications, activities of private actors are generally not imputed to member states, and the WTO's adjudicative bodies attribute such private acts to governments only in cases where the particular state is involved in the specific illegal restrictive measure (e.g., through providing incentives, delegating authority or endorsing the private actor). ${ }^{19}$ The Panel's decision in the Japan-Film case wellillustrates the WTO's jurisprudence in this sphere. ${ }^{20}$

The above WTO jurisprudence is largely consistent with the rules of international customary law regarding the attribution of 'private actions' to states (prominently, articles 4, 5, 8 and 11 of the ILC's Rules on Responsibility of States). Positive obligations arising from Article 13 of the SPS Agreement (to take 'reasonable measures'), are prevalent in general international law; but are quite rare in WTO law (which generally focuses on 'negative' obligations, such as non-discrimination).

Some judgements by the International Court of Justice (ICJ) suggest that international law includes a general obligation by states to employ 'due diligence' measures to prevent breaches of other states' legal rights by private parties operating in their territory. ${ }^{21}$ In addition, quite a few treaties bind the territorial

\footnotetext{
${ }^{19}$ See, e.g., regarding Article XI of the GATT, Petros C Mavroidis, Trade in Goods: The GATT and the Other Agreements Regulating Trade in Goods (2nd edn, OUP, 2012) 71; Rudiger Wolfrum, 'Article XI' in Holger Hestermeyer, Rudiger Wolfrum, and Peter Tobias Stoll (eds), Max Planck Commentaries on World Trade Law: WTO - Trade in Goods (Martinus Nijhoff, 2011) 281, at 289290.

${ }^{20}$ WTO, Japan - Measures Affecting Consumer Photographic Film and Paper, Report of the Panel (13 June 1996) WT/DS44, at [10.52] and [10.56].

${ }^{21}$ See, e.g., Corfu Channel Case (UK v Albania) (Merits) [1949] ICJ Rep 22.
} 
state to adopt certain measures according to the 'due diligence' standard in order to prevent breaches of international law undertaken by private actors; e.g., in the spheres of international investment law (e.g., regarding 'full protection and security'), international humanitarian law (e.g., regarding the protection of POWs), international human rights law (e.g., regarding racial discrimination), transnational criminal law (e.g., regarding terror financing), international environmental law (e.g., regarding transnational environmental damage), law of the sea (e.g., regarding protecting the marine environment), and diplomatic law (e.g., regarding the protection of the premises of diplomatic missions). ${ }^{22}$

Assigning some positive 'due diligence' obligations to WTO members vis-a-vis certain private standard-setting bodies is justified not only by the ordinary meaning of the text of Article 13; but also by broader policy considerations relating to the hybrid private-public nature of many operations of such bodies as well as the major aim of the WTO regarding the striking of a balance between trade liberalization and other societal objectives. The discussion on PSs turns the spotlight to a broader trend in international economic law regarding the increasing role of private parties in spheres that have been traditionally considered 'public spheres'. In many cases, private standards include hybrid requirements deriving from both public laws (e.g., health, safety or environmental laws) and non-binding 'good practices'. Thus, PSs such as some GLOBALG.A.P. schemes embed rules derived from public laws (enforced by private inspectors) and blur the boundaries between the public and private realms. ${ }^{23}$ Some authors are of the view that GLOBALG.A.P.'s existence is the result of, inter alia, "public authorities transferring responsibility for food safety and food quality over to the food industry". ${ }^{24}$

The growing role of private parties in international economic relations and their

\footnotetext{
${ }^{22}$ Study Group on Due Diligence in International Law, 'First Report' in International Law Association Report of the Seventy-Sixth Conference (Washington 2014) (International Law Association, London 2014) 947 , at 9535 et seq.

${ }^{23}$ De Raymond and Bonnaud, above $\mathrm{n} 3$, at 227-228, 233, 243,

${ }^{24}$ De Raymond and Bonnard, above n 3, at 230 and see the reference therein..
} 
impact on public interests suggest that the international legal system should devise adequate rules to protect the public interest, and particularly the rights of weaker parties (like developing countries). In light of the on-going (though partial) trend of enforcing public food safety standards through private bodies and blurring the lines between the private and public realms, it is not desirable that WTO law in this sphere absolves states from any duties regarding private standards which are inconsistent with the principles of the SPS Agreement. In such cases, it is justified to move beyond the traditional public-private dichotomy adopted by the WTO in other spheres, and assign some moderate obligations to the members in which such private bodies operate.

The WTO aims to expand international trade and strike an appropriate balance between the aspiration to remove trade barriers and protect other social objectives (such as protecting human, animal or plant life or health). While in the past it was clear that the significant threats to the expansion of trade were posed by public actors, contemporary trade in food products is increasingly influenced by private safety standards, some of which constitute significant NTBs. Absolving WTO members from any obligation vis-à-vis private standard setting bodies may significantly reduce the WTO's capacity to assess whether such standards justifiably restrict international trade. PSs in this sphere are too important to be removed from the scrutiny of WTO law. Since changing the SPS Agreement (or other agreements applicable to this sphere) is likely to face considerable difficulties, the WTO's dispute settlement bodies are called upon to interpret the SPS provisions according to the above ordinary meaning of the relevant provisions (prominently Article 13) and effectively respond to the new challenges.

The text of Article 13 strikes an adequate balance between the non-attribution of PSs to WTO members and the need to avoid excessive restrictive trade impacts generated by private standard -setting entities. The balance selected by the drafters of this provision assigns a relatively moderate obligation to WTO members, i.e., to 
adopt reasonable measures as may be available to them to ensure compliance by private-standard-setting bodies.

\section{The Way Forward: Implementing the SPS's Implementation Clause}

The third sentence of Article 13 does not directly impose obligations on private standard-setting bodies; nor does it impute their activities to the governments of WTO members. This provision, however, binds WTO members to "take such reasonable measures as may be available to them to ensure that" such private entities within their territories "comply with the relevant provisions of" the SPS Agreement. Though this provision assigns a relatively moderate obligation to WTO members, the governments of the members are not allowed to adopt a passive attitude regarding the interaction between PSs and the SPS Agreement's disciplines. Specific obligations imposed on WTO members in this context may be informed by the 'due diligence' principle in international customary law. In light of the elusive nature of this latter principle, the significant question is what kind of measures are to be undertaken by governments in order to satisfy this requirement? WTO members may implement this moderate obligation through a broad range of measures, and in light of the early stage of this research-work, we can only offer but a few examples:

1. Monitoring and evaluating the consistency of PSs with the SPS Agreement' principles.

2. Evaluation of the adverse effects of PSs on third parties, particularly developing countries.

3. Once the above evaluation raises concerns that the specific PS is inconsistent with the SPS Agreement's principles and that it generates restrictive impacts - publicizing information about these inconsistencies and effects.

4. Once the above concerns exist, holding a dialogue between the government and the particular private-setting entity, aiming at persuading the latter to comply with the principles of SPS Agreement. 
5. Providing adequate incentives to private-standard setting bodies complying with the SPS's Agreement's principles.

6. Requiring private-standard-setting bodies to publicize in advance new proposed PSs (and when deviating from national or international standards publicizing a brief summary of the scientific justification behind the deviation); enabling third parties to submit their response to the proposed PSs (including civil society organizations and potentially affected trading partners).

7. Where the above third parties are interested in holding a dialogue with the private-standard-setting entity concerning the necessity and impacts of the specific $\mathrm{PS}$, requiring the latter to hold such dialogue. 